\section{EDUCATION}

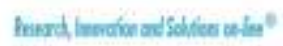

Electronic Journal of Research

in Educational Psychology

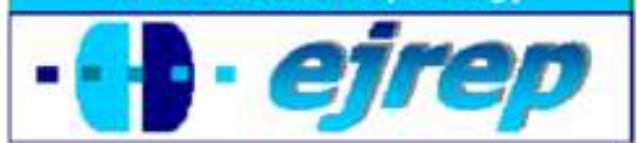

Editorial EOS

\title{
An induction programme for Bologna first-year bachelor's degree students in Spain
}

\section{Isabel del-Arco Bravo ${ }^{1}$, Ramon Camats ${ }^{1}$, Oscar Flores ${ }^{1}$, Francisco Alaminos ${ }^{1}$, José Blázquez ${ }^{1}$}

\footnotetext{
${ }^{1}$ Department of Pedagogy and Psychology, University of Lleida
}

\section{Spain}




\section{Abstract}

Introduction. The current study describes the planning process and aims of the university reforms in Spain and suggests an innovative proposal, namely the design and evaluation of a week-long induction programme for first-year bachelor's degree students at the University of Lleida (Spain), organised within the European higher education framework. The purpose of this induction programme is to help new students adapt to university life.

Method. A total of 102 students and ten lecturers were involved in the study. These participants responded questionnaires and interviews. We contrasted all the results in order to obtain some results that were useful to evaluate the induction programmee which the University introduced in the first four degrees.

Results. Findings of the study revealed that participants gave very positive feedback regarding the programme, and the results also highlighted areas which could be improved.

Conclusion. The new proposals clearly require a higher level of staff participation to make them work, highlighting the need for appropriate training of university staff and improving coordination with appropriate systems.

Keywords: Induction programme, European higher education, Bologna Process, University reforms. 


\section{Programa de iniciación para alumnos del primer curso de grado (plan Bolonia) en España}

\section{Resumen}

Introducción. El presente estudio describe el proceso de planificación y los objetivos de las reformas universitarias en España y presenta una propuesta innovadora: el diseño y evaluación de un programa de acogida de una semana de duración para estudiantes de grado de primer año en la Universidad de Lleida (España), organizado en el marco del Espacio Europeo de Educación Superior. El propósito de este programa de acogida es ayudar a los estudiantes nuevos a adaptarse a la vida universitaria.

Método. Un total de 102 estudiantes y diez profesores participaron en el estudio. Estos participantes respondieron cuestionarios y entrevistas triangulando los resultados obtenidos para así obtener datos que permitieran evaluar el programa de acogida implementado en los cuatro primeros grados

Resultados. Los resultados del estudio revelaron que los participantes dieron una respuesta muy positiva con respecto al programa, y los resultados también pusieron de relieve las áreas que podrían mejorarse.

Conclusión. Las nuevas propuestas claramente requieren un mayor nivel de participación del personal para que funcionen, evidenciando la necesidad de una formación adecuada del personal universitario y mejorando los sistemas adecuados de coordinación.

Palabras Clave: Programa de acogida, Espacio Europeo de Educación Superior, proceso de Bolonia, reformas universitarias.

Recepción:07/01/2011 Aceptación inicial: 28/01/2011 Aceptación final: 24/03/2011 


\section{Introduction}

At the end of the first decade of the twenty-first century the Spanish university system is fully engaged with the process of converging into the European Higher Education Area (EHEA), thereby meeting the challenge set through the agreement signed by the majority of European education ministries in 1999, what is widely known as the Bologna Declaration. For centuries, Spanish universities were archetypal scientific/educational institutions, and were concerned mainly with passing on scientific, technical and academic knowledge. By the turn of the twentieth century, however, there was a shift away from this minority focus towards a notion of the university as an institution for the masses, one that began to show ever increasing diversity. As a result, the concept of education as the passing on of knowledge began to lose ground, it being superseded by an emphasis on innovation and the new social and educational demands at European level. At all events, the Bologna Declaration has set a number of difficult challenges for the Spanish university system, and its implementation will require considerable effort and the incorporation of new parameters into the educational model, in the widest sense of this term.

\section{Planning and implementation of first-year degree studies in Spain}

The Spanish universities begin to adaptate to the Bologna's process since the passing of Royal Decree 1393, published on 29 October, 2007. This legal framework sets some basic principles to start a new programation in university degrees. So the Spanish universities have undertaken a planning process which will be subsequently verified and authorised through the implementation of first-year degree studies. The new legal framework has several key features:

- It has respect for university autonomy.

- It promotes university autonomy.

- It encourages flexibility in the organisation of university studies.

- It implies a change in methodology: the student is now the centre of a training period, which itself is regarded as life-long.

- It encourages skills-based planning.

- It gives priority to bachelor's degrees which are job orientated. 
- It requires the development of quality systems, both internal and external to the university, and emphasises the importance of transparency.

- It encourages student mobility and the opening up of university organisations, as well as cooperation and a commitment to training and research.

- It recognises the importance of entry procedures for training programmes so as to encourage the enrolment of foreign students, so the Article 14.2 of Royal Decree 1393, states that universities should have accessible information systems and a programme of induction and guidance for new students to help them adapt to their corresponding university studies.

In addition to the above, which provides a legal basis for the organisation and structure of university education in Spain, the university reforms have a number of other implicit goals.

- To reorganise the educational aims of the Spanish university system by unifying the former university system based on Diplomas (three years training) and Bachelor's degrees (four and five years training), which used to be the Spanish system, into a new one based in Bachelor's and Master's degrees.

- To provide students with specialised education through Master's degrees. This will promote professionalisation, internationalisation and a greater emphasis on research.

- To examine student drop-out levels and raise pass rates across the board, especially on those degrees which in the past have produced unsatisfactory results.

- To promote higher education and the status of the university in relation to both bachelor's degrees and life-long learning.

After the definition of the general framework in which to introduce the planning of new Bachelor's degrees, and after having met all the legal requirements which ensure the accreditation of the degree in terms of academic quality and authorization on behalf of the appropriate authority to go ahead with the introduction, we have still the challenge of the degree's implementation, this being the focus of the present study.

Methods of induction and a satisfactory tutorial programme are essential for both students and teachers (Filella et al., 2008). Initial experiences within the university can be deci- 
sive for later success, which is why it is necessary to adapt the induction process to the new situation. The new European higher education framework is a good opportunity to set challenges, since one of the main aims of university education is the complete education of the student (Toscano, 2002) and promotes quality enhancement mechanisms and their implications for quality cultures in universities (Gvaramadze, 2008, Marland, 2003). There is an extensive literature on the transition from school to university at least in English speaking countries.

\section{Reception and induction by universities}

Recent studies about university integration show that the first few days at university mark an important period in which influential decisions are made as the student enters new situations in both personal and academic life. Coulon (1997) states that students, on arriving at university, have to "get sharp", that is, adopt a new social status in accordance with new social codes and the university context. All this requires a learning period, a 'culturalisation'.Speaking of that, this "culturalisation" process consists in some tasks, as follows: The first task for the student is to understand the parameters of the university culture, i.e. the organisation of the institution, its academic vocabulary, (accreditation, core subjects, credits, etc.), and its rituals (the official opening of the course, award ceremonies, etc.). These are all factors which, along with the inevitable 'hidden curriculum' (Torres, 2005), form part of any organisation, and they can produce feelings of abandonment and failure through misunderstandings, wrong interpretations or simply ignorance. An induction plan for new students can be a way of helping them over the hurdles they will meet, making it easier for them to integrate and encouraging their personal autonomy. The effect of these structural relationships becomes especially evident when students are at the end of their education. However, various authors such as Rodríguez (1993, 1997), Lázaro (1997) and Salmerón (2001) point out that there are very few systematic and coherent theory/practice models of university induction. This means that in the majority of cases, universities implement services or action plans which offer the student little more than information to help them solve administrative problems. However, the situation facing today's future graduates is such that a well-drawn-up plan of induction and guidance is required. This plan should have several clear objectives:

- To encourage students to integrate and get involved in university life. Greater motivation will improve academic achievement, thereby reducing 
the drop-out rate, the causes of which are often related to a lack of motivation for studying. The first years at university are a very important influence as regards future outcomes (Lundell, Higbee, Duranczyk \& Goff, 2007). To make students aware of the help and support which are available from the institution during the period of teaching/learning.

- To make an initial diagnosis of student and group needs so that the educational process can be designed accordingly. This should lead to the drawing up of a student guidance plan, which will be implemented as part of the institution's tutorial system.

During the first few days at university the student has to make important decisions of both a personal and academic nature, ones for which he/she often does not feel prepared. Therefore, universities need to have in place a systematic induction plan. Studies in this area show how important these programmes are in terms of increasing the participation of students and improving the relationship with the institution, thereby easing the transition to university life (Inkelas, Daver, Vogt \& Leonard, 2007). Student guidance programmes can be summarised as follows:

Table 1. Different Branches of Student Guidance Programmes at University

\begin{tabular}{|c|c|c|}
\hline $\begin{array}{l}\text { Information and work } \\
\text { guidance }\end{array}$ & Psychological support & Information about other services \\
\hline $\begin{array}{l}\text { Information about } \\
\text { the world of work } \\
\text { Employment office, } \\
\text { writing a curriculum } \\
\text { Careers guidance, } \\
\text { e.g. British Career } \\
\text { Services }\end{array}$ & $\begin{array}{l}\text { Individualised help to } \\
\text { resolve personal prob- } \\
\text { lems } \\
\text { - Therapeutic or clinical } \\
\text { help } \\
\text { - Counselling service }\end{array}$ & $\begin{array}{l}\text { - Academic information } \\
\text { - Where to get further information, } \\
\text { specific services: library, student } \\
\text { services, grants, etc. } \\
\text { - Information about the structure of } \\
\text { the university } \\
\text { - Administrative information }\end{array}$ \\
\hline
\end{tabular}

There is a clear lack of relationship between teaching issues and the overall education provided by the university.

Having reviewed the induction proposals endorsed by Spanish universities, as well as the research carried out by González-Quiroga (2009), the programmed activities for the Spanish context can be summarised as follows: 
Table 2. Induction Activities in Spanish Universities

- Open Day: with general information about the university.

- Institutional induction days: information includes a training workshop.

- Induction fair: with different stands, where as well as the different university services, there is collaboration from companies, government agencies, etc. The idea is to inform students of the different services available, by means of more informal activities.

- Induction days: with families and students invited. Aims are similar to those of open days in other universities. Includes guided tours of the campus and faculties, as well as explanation of the registration process, etc.

- Mentoring days: Established students act as mentors to new students during the first few days of the course. They also act as mentors to any foreign students who arrive late to an Erasmus course which has already started.

\section{Context and aims of the present study}

The present study was conducted at the University of Lleida (UdL), which currently caters for around 9,000 students. The UdL specialises particularly in teaching and research in the field of agricultural and agro-food studies, although it also offers many other degree courses (health, education, humanities, engineering, etc.), thereby ensuring that it fulfils its objective as a centre for promoting knowledge. During the academic year 2008-09, new bachelor's degree courses -which replaced the former ones- were offered in accordance with the new EHEA. Whith that, the university, was facing two key challenges:

(1) To offer a new degree course, namely Animal Health and Science, one which had not previously been available in Spain.

(2) To reorganise three arts and humanities degrees. These degrees featured in the Pilot Plan drawn up by the universities ministry of the Catalan government.

In these cases it was necessary to take into account the low numbers of students registering for humanity degrees, as well as the fact that there was no tradition of a degree in animal health. In such a context, enrolment is likely to decrease if new students do not have a clear sense of what these new degrees involve. An induction programme for new students was therefore implemented. The programme schedule was established by the institution and different workshops were run for students in which they could acquire skills that would be 
useful during their university degree. An example of how the programme framework was implemented is given below.

Table 3. Framework of the Induction Programme for the 2008-09 Academic Year

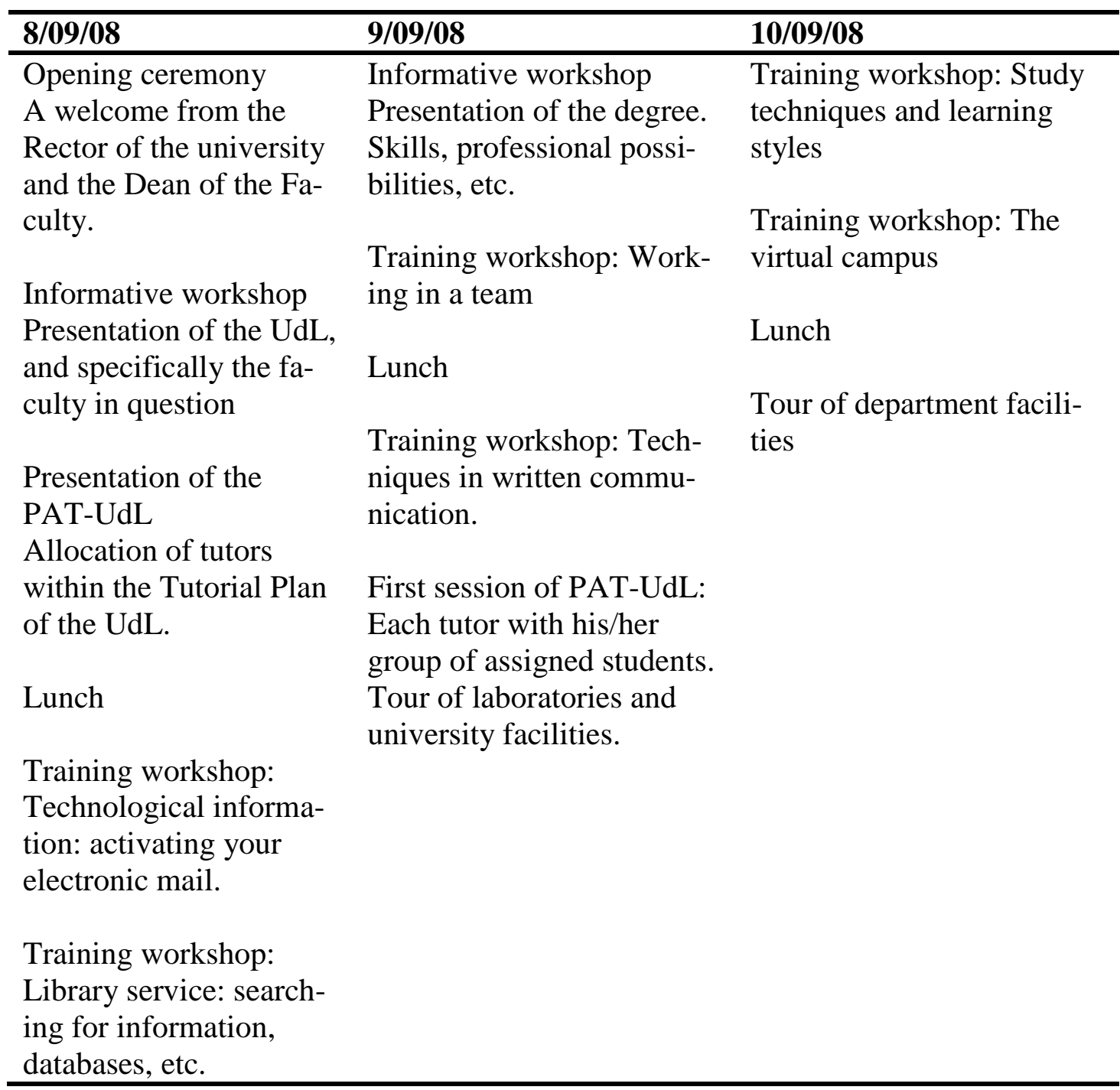

Each department of the UdL implemented the proposal in accordance with its own characteristics. Clearly, the way in which the programme is carried out is as important as its follow up and evaluation, since it serves as a source of data which can then be used to improve the plan and take into account the real needs of students. Here, data were gathered after the induction programme by asking students to complete questionnaires, as well as through semi-structured interviews with the participating lecturers. In this context, the aims of the present study: 
(1) To determine how much knowledge and information, and how many expectations, new students had gained from the first-year student training programme for their chosen degree.

(2) To record the appraisals, needs covered and future suggestions of students with respect to the induction programme already in use, as well as those of participating lecturers.

(3) To establish key guidelines for developing and implementing a systematic induction programme for future students at the UdL, thus ensuring that the proposals could be carried out.

\section{Method}

\section{Participants}

The sample comprised all first-year students enrolled in the 2008-09 academic year at the University of Lleida. These students were the first full cohort to begin their studies following the application of the European higher education framework to the Spanish university system. It should be noted, however, that during this academic year there was some overlap, with the old degrees (diploma and undergraduate degrees) still being applicable in some universities, while in others bachelor degrees appeared for the first time. From a total of 102 first-year students who participated in the induction programme, 76 responded to the questionnaires. Ten lecturers were also interviewed in order to evaluate their experiences. We have to consider that this year we introduced only four new Bachelor's degrees.

\section{Instruments}

In line with the stated aims of the study, two methods were used:

(1) A questionnaire to record students' appraisals. This questionnaire was previously validated by ten experts, who analysed it in terms of accuracy. The questionnaire was divided into two sections. The first section, comprising 16 items, gathered students' 
opinions about the new student guidance programme. The second section, with 21 items, focused on the induction programme and asked them about planning, participation and involvement of lecturers, adaptation of course content, and the suitability of workshops and activities. Each section included four open questions inviting students to make suggestions to improve the induction programme.

(2) A semi-structured interview designed to collect information from participating lecturers about the activities included in the induction programme. This interview comprised two main sections:

(i) Evaluation of the induction programme: strong and weak points.

(ii) Suggestions for the future.

\section{Procedure}

The study consisted of the following stages:

Table 4. Stages Study

\begin{tabular}{ll}
\hline Stage 1 & $\begin{array}{l}\text { Design of the proposed framework for the induction programme, en- } \\
\text { suring it was consistent with other departments and faculties and } \\
\text { adapted to the specific characteristics of the degree in question. }\end{array}$ \\
\hline Stage 2 & The first week of the induction programme: running workshops. \\
\hline Stage 3 & $\begin{array}{l}\text { Final evaluation of activities: administering the questionnaire to stu- } \\
\text { dents and carrying out the semi-structured interviews with teaching } \\
\text { staff. Analysis of the results obtained. }\end{array}$ \\
\hline
\end{tabular}

\section{Results}

Students. Section I: Opinions, information and expectations

These data are important as regards making any subsequent changes to procedures and the information given to secondary schools, which in turn offer educational guidance to their students. On the basis of student feedback we can complement and, if necessary, correct the information which new students are given. Furthermore, it is also possible to improve the ex- 
change of information between the university and secondary information centres, thereby aiding the transition and consolidation of access programmes.

In relation to how much they knew about the EHEA, $48.4 \%$ of students said they had received information about what the EHEA means, although $56 \%$ of these students interviewed considered that it was too general and not detailed or precise enough

(1) When asked about the fact that their bachelor's degree had been changed according to the Bologna guidelines, students said that this had not influenced their choice. Overall, $69.6 \%$ of those questioned had been informed about the skills and professional profile of the degree chosen. Breaking the responses down according to gender revealed that $75.8 \%$ of men and $83.7 \%$ of women felt that having chosen a bachelor's degree was to their advantage.

(2) A total of $68.1 \%$ of students had favourable expectations of their bachelor's degree, and considered it to be of higher quality than the previous degree courses. Not only did they expect to obtain knowledge that was more specific to their degree, but a high percentage of them (90.9\%) also expressed an interest in learning more general crossdisciplinary skills. Students said they wanted to learn about other aspects such as how to work in a team, form a critical opinion and make decisions. They also had high expectations regarding their work experience outside the university. Indeed, $80.2 \%$ of new bachelor's degree students hoped to gain work experience that would enable them to put into practice the theory they would learn at university. Overall, 95.4\% saw the new proposal of a bachelor's degree in positive terms.

\section{Students. Section II: Evaluation of the induction programme}

(1) Material and information received: $84.8 \%$ considered that they had received sufficient information to be able to access the resources available to them at university. All $(100 \%)$ the students thought that the material they had been given during the different activities was relevant and adequate. 
(2) The organization of activities: $75.6 \%$ were in favour of carrying out practical activities during the first semester, or even throughout the academic year. However, the students stated that the workshops organised were too theoretical.

(3) Social relationships: human relationships and personal contacts were both highly valued. Overall, $99 \%$ of students found the induction activities to be of great value, and felt they were worth including in the programme for what they offered in social and personal terms.

(4) $72.7 \%$ said that the programme had reduced the stress associated with starting a new course and had helped them to familiarise themselves with how the institution functioned and what was expected of them.

(5) Students made a number of suggestions about how to improve the programme: they felt that the use of informal or sport-related activities could help them to get to know both one another and the teaching staff. The guidance offered by student mentors was also mentioned as being of value. Overall, the opinions expressed by this sample of students are consistent with those reported in previous studies such as that by Lundell et al. (2007), who also collected students' opinions about an induction programme.

\section{Teaching staff. Section I: Evaluation of the induction programme}

(1) Eight out of ten of those interviewed thought that there should be a way of finding out about students' initial cross-disciplinary skills. It would then be possible to develop an induction activity that could compensate for any deficiencies.

(2) All the teaching staff interviewed felt that induction programmes in a university such as the UdL can help to foster a closer atmosphere, which is often a key aspect when students are choosing a university or decide to drop out from it.

(3) A small minority (two) of the teaching staff interviewed thought that although the induction programme was generally positive it ran the risk of appearing too paternalistic, which might be appropriate at other levels of education, but which should not be a 
characteristic of the university system: "those attending university are adults and this is how students should be treated" (opinion p. 3).

(4) $98 \%$ of those interviewed considered the possibility of starting "zero" courses to help students acquire basic skills for a specific subject. However, they did not explain how these could be included within the same academic timetable and during the first month of the course. Of this $98 \%$, those keenest to see this happen (69\%) were staff from engineering and science degrees.

(5) Weak aspects of the programme: Low participation of academic staff, particularly as regards the university's management board (opinion shared by eight of those interviewed). The teaching staff also felt that there was a lack of more informal activities that would give students the opportunity to get to know one another ( 7 out of 10 interviewed).

(6) Several lecturers mentioned the fact that many students did not understand that they had to attend induction activities a few days before the start of the course. "We happily prepare this programme and tell them they have to attend the three days of induction activities, and then they ask if it's compulsory to come..." (opinion p. 6). One possible explanation for the latter is that there is no tradition of induction programmes in the Spanish university system.

Teaching staff. Section II: Suggestions for the future

(1) The need to convince students from later academic years to act as mentors and share their experience with new students.

(2) Three of the lecturers interviewed mentioned the possibility of implementing a mentoring scheme during the academic year. Each first-year student would be assigned a mentor from higher academic years, to whom they could turn with doubts or problems of an academic nature. 
(3) The need for "zero" courses in order to consolidate students' knowledge of both basic and cross-disciplinary skills. The idea would be for these courses to take place during the first month, and they would be compulsory.

(4) There should be more informal, sport-related or cultural activities through which students could get to know one another.

\section{Conlusions and Discussion}

- Both students and teaching staff gave a positive appraisal of the induction programme. This provides the university with a quality index, showing that the programme helps students to adapt to this new stage in their education. The programme also favours academic output and reduces the rate of student drop-out.

- Students arrive at the university with a very general idea of its organisation, services, teaching and even the degree itself. The aim should therefore be to provide them with more detailed information, and from a more practical perspective.

- There seems to be little tradition of induction programmes for new students in the Spanish university system. This is illustrated by the less-than-enthusiastic involvement of teaching staff and students in the activities offered. Staff generally accepted the role of these activities, although a small percentage (5\%) questioned the need to adopt such programmes.

- Both lecturers and students said there was a need for more informal, sport-related or cultural activities that could encourage social interaction and the forming of relationships.

- A way of evaluating (level test) students' basic skills needs to be found so that these skills can then be consolidated, either through independent learning or by attending courses or workshops, on-line training, etc. 
- There is a need to establish an integrated programme in which induction and tutorial guidance can be coordinated and planned. The teaching staff highlighted the need to extend the induction workshops across the first academic year, with the possibility of others being introduced in accordance with the needs of first-year students.

- Staff felt it would be worthwhile for students from higher academic years to become actively involved in a mentoring scheme. The value of this was also acknowledged by students. One model for such a scheme would involve first-year students being assigned a mentor.

To conclude, the new proposals clearly require a higher level of staff participation to make them work, not least because there will be an increased number of activities to help the student induction process and its follow-up. This raises the need for both appropriate staff training and adequate systems of coordination. 


\section{References}

Beaupère, N., Chalumeau, L., Guri, N., \& Hugrée, C. (2007). L’Abandon des études supérieures: rapport réalisé pour l'Observatoire national de la vie étudiante. [Abandonment of higher education: report prepared by the National Observatory of Student Life.] Paris Ed.

Coulon, A. (1997). Le métier d'étudiant. L'entrée dans la vie universitaire. [The student job. The access in the university life.] Paris: PUF.

Filella, G., Lara, I., Soldevila, A., Nadal, J., Ribes, R., Agulló, M.J., \& Carrillo, F. (2008). Preliminary evaluation of the implementation of a mentorship plan in the Faculty of Education at the University of Lleida (UdL), Spain. Higher Education in Europe, $33(4), 447-456$.

Gonzalo , M (Dir) (2009). Programas de Acogida y orientación al estudiante en el marco del espacio europeo de educación superior. Servicio de publicaciones de la Universidad rey Juan Carlos. Madrid: Ed. Dykinson.

Gvaramadze, I. (2008). From quality assurance to quality enhancement in the European Higher Education Area. European Journal of Education, 43(4), 443-455.

Inkelas, K.K., Daver, Z.E., Vogt, K.E., \& Leonard, J.B. (2007). Living-learning programs and first-generation college students' academic and social transition to college. Research in Higher education, 48(4), 403-434.

Lázaro, A. (1997) La acción tutorial de la función docente universitaria. [The tutorial of the university teaching.] Revista Complutense de Educación, 8(1), 233-252.

Lundell, D., Higbee, J., Duranczyk, I., \& Goff, E. (Eds.). (2007). Student standpoints about access programs in Higher Education. Minneapolis: Center for Research on Developmental Education and Urban Literacy (CRDEUL), University of Minnesota.

Marland, M. (2003) The Transition from School to University:Who prepares whom, when, and how? Arts and Humanities in Higher Education, 2, 201-211,

Rodríguez, S. (1990). Problemática y tendencias de la orientación universitaria. [Problems and trends in college orientation.] In La Reforma Educativa: Un reto para la orientación. V Jornadas Nacionales de Orientación Educativa (pp. 107-122). Valencia: Asociación Española para la Orientación Escolar y Profesional. Delegación Territorial Valenciana. 
Rodríguez, S. (Coord.). (1993). Teoría y práctica de la orientación educativa. [Theory and practice of educational guidance.] Barcelona: PPU.

Rodríguez, S. (1997). Orientación universitaria y evaluación de la calidad. [University orientation and quality assessment.] In, P. Apodaca \& C. Lobato (Eds.), Calidad en la universidad: orientación y evaluación (pp. 112-136). Barcelona: Laertes.

Salmerón, H. (2001). Los servicios de orientación en la universidad: procesos de creación y desarrollo. [Guidance services in the university: Creation and development processes.] Ágora Digital, 2.

Steed, C., Maslow, D., \& Mazaletskaya, A. (2005). The EFQM Excellence Model for deploying quality management: A British-Russian journey. Higher Education in Europe, 30(3-4), 307-319.

Torres, J. (2005). El curriculum oculto. Madrid: Ed. Morata.

Toscano, $\mathrm{M}^{\mathrm{a}}$ de la O. (2001). Necesidad de la orientación en la Universidad. [Orientation need in the university.] Ágora Digital, 2. 